\title{
A futures study into identifying the driving forces in neighbourhood-based management, using good urban governance: The case of Region 2 in Tabriz, Iran
}

\section{Seyedeh-Samira Shafiee-Masuleh*, Seyed Reza Shafiee Masouleh \& Marzieh Rastad Borujeni}

DOI: $h t t p: / / d x . d o i . o r g / 10.18820 / 2415-0495 / t r p 76 i 1.6$

Peer reviewed and revised February 2020

Publised June 2020

${ }^{*}$ The authors declared no conflict of interest for this title or article

\begin{abstract}
This article investigates the use of futures studies to predict the implemention of a new approach to neighbourhood-based management, emphasising good urban governance components in the planning and management of the Tabriz metropolis, Iran. Using a qualititative approach, the Delphi technique, comprising two rounds, was used to identify the initial and key factors that affect the realisation of neighbourhoodbased management. Using questionnaires, in Round 1, participants answered one question on what they predict the key factors for good urban governance are and, in Round 2, they weighted the 48 identified initial factors from Round 1 in a matrix, on an 4-point Likert scale, to determine the influence on each factor. Cross-impact analysis of the influence data were extracted by MICMAC software and results showed 17 driving forces (eight in accountability, five in equity, two in transparency and one in participation) that will predict the realisation of good neighbourhood-based management in the planning and management of the Tabriz metropolis. Findings showed that futures studies can be used as a new approach to accurately identify the driving forces for good urban governance with the realistic use of the capabilities of the community.
\end{abstract}

Keywords: Cross-impact analysis, Delphi technique, futures studies, good urban governance, Iran, neighbourhood-based management, structural analysis

\section{'N TOEKOMSSTUDIE VAN DIE DRYFKRAGTE IN BUURTGEBASEERDE BESTUUR MET BEHULP VAN GOEIE STEDELIKE BESTUUR: DIE GEVAL VAN STREEK 2 IN TABRIZ, IRAN}

Hierdie artikel ondersoek die gebruik van toekomsstudies om die implementering van 'n nuwe benadering tot buurtgebaseerde bestuur te voorspel, met die nadruk op goeie stedelike bestuurskomponente in die beplanning en bestuur van die Tabriz-metropool, Iran. 'n Kwalitatiewe benadering, met die Delphi-tegniek, wat uit twee rondtes bestaan, is gebruik om die aanvanklike en sleutelfaktore wat die verwesenliking van buurtgebaseerde bestuur beïnvloed, te identifiseer. Met behulp van vraelyste, in Rondte 1 , het die deelnemers een vraag beantwoord oor wat hulle voorspel die sleutelfaktore vir goeie stedelike bestuur is, en in Rondte 2 het hulle die 48 geïdentifiseerde aanvanklike faktore uit Rondte 1 in 'n matriks op 'n 4-punt Likert-skaal geweeg om die invloed op elke faktor te bepaal. Kruis-impakanalise van die invloeddata is onttrek deur MICMAC-sagteware en die resultate het 17 dryfkragte getoon (agt in verantwoordbaarheid, vyf in ekwiteit, twee in deursigtigheid en een in deelname) wat die verwesenliking van goeie buurtgebaseerde bestuur in die beplanning en bestuur van die Tabrizmetropool sal voorspel. Die bevindinge het getoon dat toekomsstudies as 'n nuwe benadering gebruik kan word om die dryfkragte vir goeie stedelike bestuur akkuraat te identifiseer met die realistiese gebruik van die vermoëns van die gemeenskap.

Sleutelwoorde: Kruis-impakanalise, Delphi-tegniek, futures studies, goeie stedelike bestuur, Iran, buurtgebaseerde bestuur, strukturele analise

\section{PHUPUTSO EA BOKAMOSO \\ E MABAPI LE HO HLWAYA MEHLOLI EA BOTSAMAISI BO BOTLE TAOLONG EA LITOROPO, BOITHUTO BA TIKOLOHO EA BOBELI EA TABRIZ, NAHENG EA IRAN}

Sengoloa sena se lekola tšebeliso ea lithuto tsa bokamoso ho nahana tshebeliso ea mokhoa o mocha oa botsamaisi ba tikoloho, 'me o totobatsa likarolo tse ntle tsa taolo ea litoropo meralong ea totopo ea Tabriz, Iran. Phuputso ena e sebelisitse mokhoa oa boleng oa boithuto oa Delphi, o kenyellelitseng methati e mmeli ea ho bokeletsa thlahiso leseling ele ho supa lintlha tsa manthla le tsa bohlokoa tse amang ho phethahala ha taolo ea baahi. $\mathrm{Ka}$ tshebeliso ea tokomane ea lipotso, mothati oa pele (1) o botsitse ba nkileng karolo ho hakanya linthla tsa bohlokoa bakeng sa taolo e ntle ea litoropo, mme mothating oa bobeli (2) ba lekanya lintlha tse 48 tse khethiloeng mothating oa pele, ka tshebeliso ea tekanyo e nthla-nne ea Likert ho tseba tšusumetso lebakeng ka leng. 'MICMAC software' e sebelisitsoe ho hlahloba tshutshumetso ea linthla tse fumanoeng, mme liphetho li bontsha mehloli e 17 (e 8 ea boikarabello, e 5 ea tekatekano, e 2 ea botshepehi le o 1 oa ho nka karolo) ea ponelopele phethahatsong ea taolo e ntle meralong ea tsamaiso ea tikoloho toropong ea Tabriz. Phuputso e

Ms Seyedeh-Samira Shafiee-Masuleh, *(corresponding author) PhD. candidate, Department of Geography and Urban Planning, University of Tabriz, Tabriz, East Azerbaijan, Iran. Phone: +98911927 6012, Email: <s.shafiee@tabrizu.ac.ir>

Mr Seyed Reza Shafiee Masouleh, MA, Department of Geography and Urban Planning, University of Guilan, Rasht, Guilan, Iran.

Phone: +98 911839 8476, Email: <rshafiei210@gmail.com>

Ms Marzieh Rastad Borujeni, PhD. candidate, Department of Geography and Urban Planning, University of Tabriz, Tabriz, East Azerbaijan, Iran; Tel: +98 919645 1264, Email: <m.rastad@tabrizu.ac.ir> 
bonts'itse hore lithuto tsa bokamoso li ka sebelisoa e le mokhoa o mocha oa ho khetholla ka nepo sephetho sa taolo e ntle ea litoropo ka ts'ebeliso ea sebele ea bokhoni ba sechaba.

\section{INTRODUCTION}

Management structure in the metropolises of Iran, a country in Western Asia and a member of the Middle East and North Africa (MENA) region, despite the formation of Islamic City Councils, does not have the characteristics of a modern, democratic local participatory management (good urban governance). Most of the institutions and actors involved in the management of the Tehran metropolis were state-owned, and the non-governmental organisations (NGOs) had limited and contingent participation in the administration of city affairs, showing a lack of political, legal and executive decentralisation and thus inequality in the distribution of power in the management of the Tehran metropolis (Pišgāhi-Fard, Qalibāf, Morādl-Nia \& Mo'meni, 2013; Razaviyān, Tavakkoli-Nia, Qurči \& Rostami, 2015).

According to Rezā'i and Mo'azzen (2017), urban management of the Tehran Regions is not in a desirable condition relative to the components of good urban governance as neighbourhood management, and, consequently, citizens are still far from the good model that requires full participation, on the one hand, and the full delegation of authority, on the other. The experience of various countries in urban development projects suggested that the success of projects is dependent on the participation of people and local institutions (Rajabi, 2011).

According to Fanni and Sāremi (2008: 91), Tabriz, the largest metropolis in north-western Iran, has the same semi-modernist structural features and constraints in the macrosystem as that of the country's urban management, namely noncooperative; centralised; sectoral; top-down; bureaucratic; politically motivated; lacking in thought and urban development processes; lack of a practical commitment to the urban development principles and plans; lack of systematic planning and capacity for urban development; lack of hierarchical conformance of the management structure to the spatial organisation of the city; lack of organisational discipline in terms of the contradictions of structure and function; lack of structural discipline in terms of the relevance of the levels of organisational structure; the existence of a vacuum in some of the structural elements approved in the existing structure; the existence of structural elements outside the necessity and will of the organisation in the existing structure; inflexibility in the pattern of the organisational structure in terms of participation in intragroup activities, and structural sustainability against transformation.

For this reason, this article proposes to turn to a neighbourhood-based management system in Iran, using the components of good urban governance. The question is: What is the relationship between the neighbourhood-based management system and an approach to good urban governance?

Razaviyān et al. (2015: 515) stated that, in an approach to good urban governance, neighbourhoods provide the role of social reproduction of the new mechanisms of power, by creating the context for the emergence of other agents from the private and popular sectors. This means that government, civil society and the private sector are three fundamental elements of good urban governance. According to Razaviyān et al. (2015: 515), neighbourhood-based management also provides the groundwork for the horizontal process of interaction between institutions and actors of good urban governance, including citizen participation; support and cooperation between neighbourhood management and the private sector and civil society; participation of people of the neighbourhood in the city administration, and doing some of the activities of the neighbourhood with the coordination of citizens.
As set out by the United Nations Habitat, Taqvā'i and Tājdār (2009: 3-4) consider participation, effectiveness and efficiency, responsiveness, accountability, transparency, rule of law, consensus orientation, equity, strategic vision, and decentralisation as the components of good urban governance in Iran. For analysing neighbourhood-based management, based on the components of good urban governance, this article chooses the four components of participation, equity, accountability, and transparency.

In Iran, the field of foresight and specialised planning is still in its early stages. It was thus futile to research previous studies directly and independently based on the analysis of neighbourhoodbased management, founded on the components of good urban governance, with an approach to futures studies. Therefore, this article is a novel movement for explaining a futures studies approach in the field of neighbourhood-based management. It determines whether it is possible to implement a new approach to neighbourhood-based management, emphasising the components of good urban governance in the planning and management of the metropolis of Tabriz. To do this, it was important to predict the driving forces or key factors affecting this, by making use of the futures studies approach.

\section{THEORETICAL FOUNDATIONS}

\subsection{Neighbourhood-based management}

The realisation of neighbourhoodbased management, founded on good urban governance, is related to decentralisation, methods of citizen participation in urban development plans and programmes, as well as the status of councils and municipalities in society. The role of neighbourhood management should be controlled beyond the capacity of governments, in improving the situation of people (Bazi, Mirkatuli \& Zāyedli, 2017: 151). 
Neighbourhood-based management can be viewed as a bridge between a coherent local community and a central government (Nuriyān \& Mozaffaripur, 2013: 49). The concept of a coherent local community is a network of local communities with identities, interests and common theories at the local level that provide the areas of knowledge, building opportunity, and a twoway support for mutual interaction (Barton, Grant \& Guise, 2003: 4). The use of the term 'neighbourhoodbased management' instead of 'local government' is an attempt to depoliticise from the local government and to maintain a technocracy (Nuriyān \& Mozaffaripur, 2013: 49). In fact, this kind of structural change management is for realising the neighbourhood-based approach (see Table 1). The goal of the neighbourhood-based approach is to bring together the various groups involved or interested in planning and addressing their needs and wishes in the formulation of programmes. As a new method of urban management emphasising local communities, this approach can be considered an inseparable part of the decentralisation problem. The features of the neighbourhoodbased approach are: (1) It is a people-oriented approach and citizens are at the centre of its attention; (2) it is participatory and accountable; (3) it is holistic and pays attention to all aspects of the lives of citizens; (4) it relies on existing capabilities and opportunities, and is not necessarily needs based (capacity-building); (5) it uses a cooperative approach between the government, the private sector and local communities (paying attention to good urban governance); (6) any type of intervention in this approach takes into account the aspects of economic, environmental, social and institutional sustainability, and (7) the dynamism and flexibility that view the planning activity as a process and learning approach (Azimi-Āmoli \& Eršādi-Vahrām, 2017: 23-24).

In short, the concepts of down-top planning, collective and inclusive participation, greater choice for local residents, social equity, building equal opportunities, along with more efficiency, fair distribution of amenities and development benefits, as well as the people's welfare (not simply to people a place) become apparent only in light of the concept of 'local development' and the planning of urban neighbourhoods (Fanni \& Sāremi, 2008: 92).

\subsection{Good urban governance}

Governance is a combination of both formal and nonformal, vertical and horizontal arrangements that have major significance for public issues, herein the urban realm (Hendriks, 2014: 4). It is a complex concept. The simplest definition of governance is the quality of the relationship between the government and its citizens. In other words, governance is the quality of the process whereby decisions are made that influence public issues, as well as the quality of the implementation and the consequences of the decisions (Sheng, 2010: 134).

Urban governance relies on selforganised networks and down-top approaches and views citizens as actors and participants in important decisions for the implementation and urban policy-making process. As a result, urban governance is seeking collective action through mobilising partnerships, consensus, participation, interrelationships, social capital, empowerment, and responsibility in the urban policy-making process (Kim \& Dickey, 2006: 1037).

One of the significant components of good urban management is good urban governance. Good urban governance suggests that all citizens, including the poor, marginalised groups, have the right to participate directly or indirectly in decisions that affect their lives and livelihoods. Their contribution to urban development should be acknowledged, even if this is done through informal sectors, and they should contribute to the benefits of urban development such as access to service, infrastructure, and land for building housing (Sheng, 2010: 134-135). Therefore, it appears alongside terms such as human rights, democracy, civil

Table 1: $\quad$ Main services for neighbourhood management and prerequisites for its success

\begin{tabular}{|c|c|}
\hline Main services & $\begin{array}{l}\text { - } \\
\text { - } \\
\text { Environmental protection and restoration of damages to public areas; } \\
\text { - } \quad \text { Cleaning the street, collecting and moving waste; } \\
\text { - } \quad \text { Community communication, contact, consultation and support; } \\
\text { aligning inputs to maximise benefits and minimise waste and overlap; this } \\
\text { includes housing, restoration, health, education, supervision and restoring } \\
\text { order, leisure and reconstruction; } \\
\text { - Connecting with local businesses; } \\
\text { Connecting with a more central and wider service that is essential for the } \\
\text { - } \quad \text { successful function of a neighbourhood; for example, adult education, job } \\
\text { - } \quad \text { Centre, library; } \\
\text { Coordination with, and support for local voluntary groups. }\end{array}$ \\
\hline $\begin{array}{l}\text { Preconditions for } \\
\text { success }\end{array}$ & $\begin{array}{l}\text { - The area designated for action; } \\
\text { - An administrator with a sufficient history to control and coordinate the main } \\
\text { service inputs; } \\
\text { A small team of local staff based on local responsibility for implementing } \\
\text { management decisions; } \\
\text { Defined budget for team procurement and agreed services, and the } \\
\text { feasibility of flexible local management decisions; } \\
\text { - A local base where service can be organised, communicated and } \\
\text { familiarised with local residents; } \\
\text { Prioritising basic service to have a concrete impact on conditions, thereby } \\
\text { gaining confidence and supporting other services such as doctors and } \\
\text { schools; } \\
\text { Entrepreneurial approach to solving the problem and including shared } \\
\text { - } \quad \text { Clear guidelines for communicating with local policymakers and other } \\
\text { decision and service bodies; } \\
\text { Long-term financing; not short-term, project-based financing. }\end{array}$ \\
\hline
\end{tabular}

Source: Power, 2004: 3 
society, and participation, and helps develop these concepts (Rezazadeh, 2011: 260). In brief, good urban governance is an essential ingredient to achieve sustainable and equitable growth and development (Jiboye, 2011: 213).

The components of governance, like its concept, have been accompanied by various changes and definitions by a number of authors and experts. In this context, the United Nations Habitat considers the nine components of good urban governance as follows.

According to studies on good urban governance and its conformity to the conditions of the cities of Iran, participation, effectiveness and efficiency, responsiveness, accountability, transparency, rule of law, consensus orientation, equity, strategic vision, and decentralisation have been named as the components of good urban governance in Iran. The latter highlights the giving of power to different organisations and centres and the competence of local institutions to carry out tasks. Decentralisation is based on the principle of "delegation of responsibility to a lower level" (Taqvā'i \& Tājdār, 2009: 54).

\subsection{Neighbourhood-based management and good urban governance}

Neighbourhood management is an independent level of the government (municipality, city council); its main goal is to improve the neighbourhood conditions by negotiating with the government levels and repairing the gap between citizens and government elements. There are two views for the city's general administration. First, as municipality, the government is responsible for all the affairs (the task of providing services to civil society). The second view is based on good governance and is close to neighbourhood management, because, in this instance, there is a division of tasks. In this view, the municipality serves as a representative of the

Table 2: Components of good urban governance

\begin{tabular}{|c|c|c|}
\hline & Component & Description \\
\hline 1 & Participation & $\begin{array}{l}\text { The purpose of participation is the power to influence decisions and citizens' } \\
\text { contribution to the power. }\end{array}$ \\
\hline 2 & Rule of law & $\begin{array}{l}\text { The purpose of the rule of law in urban decisions is the existence of effective } \\
\text { laws, the fair observance of the legal framework in the decision process, } \\
\text { and the removal of the hands of irresponsible individuals from the decisions. } \\
\text { Fidelity to the law requires the citizen's awareness of the law as well as the } \\
\text { respect of the authorities for the law. }\end{array}$ \\
\hline 3 & Transparency & $\begin{array}{l}\text { It is the opposite of secrecy in decisions. Secrecy increases the possibility } \\
\text { of corruption in decisions, while transparency prevents it from spreading. } \\
\text { This component is based on the free flow of information and ease of access } \\
\text { thereto, the clarity of actions and the citizens' continuous awareness of } \\
\text { existing processes. }\end{array}$ \\
\hline 4 & Responsibility & $\begin{array}{l}\text { This component is based on being responsible. In other words, authorities and } \\
\text { decision-makers must render an account of their actions to citizens. }\end{array}$ \\
\hline 5 & $\begin{array}{l}\text { Consensus } \\
\text { orientation }\end{array}$ & $\begin{array}{l}\text { The city is the arena of different groups and interests that sometimes conflict } \\
\text { with each other. The purpose of consensus orientation is the adjustment and } \\
\text { agreement of different interests. This involves the existence of a relationship } \\
\text { and joint effort between the governmental organisations, citizens and NGOs. }\end{array}$ \\
\hline 6 & Equity & $\begin{array}{l}\text { The purpose of equity is to create opportunities for all citizens to improve their } \\
\text { welfare status, strive for the fair allocation of resources and the participation of } \\
\text { the disadvantaged in making comments and decisions. }\end{array}$ \\
\hline 7 & $\begin{array}{l}\text { Effectiveness } \\
\text { and efficiency }\end{array}$ & $\begin{array}{l}\text { This component is based on the proper use of available resources to meet the } \\
\text { needs of citizens, the provision of urban services and people's satisfaction. }\end{array}$ \\
\hline 8 & Responsiveness & $\begin{array}{l}\text { This component includes two complementary points. Urban authorities } \\
\text { must understand and accept the needs and aspirations of the citizens, and } \\
\text { appropriately respond to them. Therefore, the citizens' demands and the } \\
\text { actions of the authorities need to be aligned. }\end{array}$ \\
\hline 9 & Strategic vision & $\begin{array}{l}\text { Going beyond the daily routines of the city and avoiding drowning in them } \\
\text { require a broad, long-term vision of the future or a strategic vision for urban } \\
\text { development. }\end{array}$ \\
\hline
\end{tabular}

Source: Tavakkoli and Mo'meni, 2016: 3-4

government, providing the necessary facilities, facilitating the role of the municipality, and providing the necessary ground for the private sector to operate. The private sector is, in fact, acting as an investor and must have the necessary guarantees for the preservation and return of capital. The third part is civil society that is passive in the first view and in this view plays the role of decision, decision-making and, above all, supervision (Rezāi and Mo'azzen, 2017: 123). In fact, urban governance establishes participation and cooperation among all effective forces such as the government, the private sector, the public sector, and popular organisations in the management of society (Taqvā'i \& Tājdār, 2009: 49). With the creation of such a situation, it is possible to realise neighbourhood management in its true sense.

\subsection{Futures studies in neighbourhood-based management}

The first work of futures studies was conducted in the form of a scientific analysis from 1930 to 1933 by a group of researchers led by Ogburn in the field of sociology in the United States of America (USA). Subsequently, the German Professor Osipp introduced the term 'futurology' from the mid-1940s, which meant a study of the future and considering the probabilities ahead. In 1984, after World War II, and following the analysis of technologies used in Germany and Japan, futures studies were introduced in the USA for a military imperative in the Rand Institute. From 1950 to 1960 , the modern futures studies field formally became known with the publication of the image of the future by Polak in 1951, and the art of guessing by Vattel in 1964 . Over time, the research institutes and the international institutes of foresight were founded and different branches of this discipline were expanded. Foresight at the national level was begun with the Japanese activity in the 1970s. In the 1990s, global conditions changed in such a way that it became compulsory 
for national actors to use foresight

(Vā'ezi, Qomiyān \& Vaqfi, 2017: 35).

With increasing changes in the late second millennium and the emergence of new issues in the global community, reliance on planning methods based on prediction was not responsive to the needs of countries' macromanagement. The dramatic shadow of uncertainties and the emergence of discontinuous events transformed the situation in such a way that predicting the future in the changing world for the planners was a problem. The inability to accurately predict the future and the complexity of the ever-increasing changes forced researchers to use the potentialities of the emerging knowledge of futures studies. Futures studies is, in fact, a knowledge that will open the people's view to the possible events, opportunities and challenges of the future and, by reducing ambiguities and doubts, increase the ability of the intelligent choices of people and society, and allow everyone to know where they can go and where they should go (Na'imi \& Purmohammadi, 2016: 54-55).

Therefore, futures studies ought to address the great human problems, including the fight against aliens; building new human houses; ending the excessive use of natural resources; preserving nature; preventing tyranny, famine and poverty; preventing war and securing peace, and increasing democracy (Kešāvarz-Tork \& Barāti, 2013), which latter case can be obtained from neighbourhood-based management.

In order to turn to a neighbourhoodbased management system in Iran, what is needed is a revision of current approaches and more precise planning such as planning with an approach to futures studies and moving towards planning based on the comprehensive recognition of all elements and factors for the satisfactory realisation of a neighbourhoodbased management system by the realistic use of the capabilities of the community. Doing so will create scenarios and formulate strategies for good urban governance.

\section{STUDY AREA}

Tabriz, the largest metropolis in northwestern Iran, with an area of roughly 24559 hectares and approximately 1340 meters above sea level, is located on the Azerbaijan plateau. The geographical location (proximity to the Anatolian Plateau, the Armenian Plateau, and Lake Urmia) has established a privileged and strategic location for this city with the intersection of valleys and gentle slopes with economic and human factors, especially political and cultural boundaries, internal communication channels, and transit routes to Iraq, Armenia, Turkey, and Azerbaijan (Hossein Pour, 2017: 68).

Tabriz has long been one of the most important urban centres in Iran in terms of economy, trade, and industry and has led to an increase in the number of immigrants and villagers and the formation of informal housing in this city. Although the quality of these settlements is unconventional and abnormal, due to basic services and the better situation of some housing indices such as durable materials, the situation is relatively more favourable than in other developing countries (Asghari Zamani, Zadvali Khaje \& Zadvali, 2010: 58-59). In this city, over 450000 people live in informal settlements, of which $56 \%$ live in the northern and north-western parts of the city (Region 6 and minor parts of Region 1) and $44 \%$ live in the south and south west of the city (Nematollahi, 2015: 38). Tabriz has ten regions, of which Region 2 is the study area. Figure 1 shows the location of Region 2 in the city.

As the largest region, including three areas, with an area of 2 096 hectares and a population of 196507 , Region 2 covers $11 \%$ of the population of Tabriz. One of the dominant features of the region is the high level of barren land. This region covers 82 hectares of land, with service uses at a per capita of 4.79 square metres. The highest level of service use in the region $(82 \%)$ is allocated to green space, education, and administrative-disciplinary uses. In addition to the lack of service use at the level of the neighbourhood, the average residential area in the region is 250 square metres (building area of $52.5 \%$ ), in which some neighbourhoods such as Yaghchiyan are only 1\%, due to modernisation based on the criteria of urban planning (Hossein Pour, 2017: 81, 84) (Figure 2).
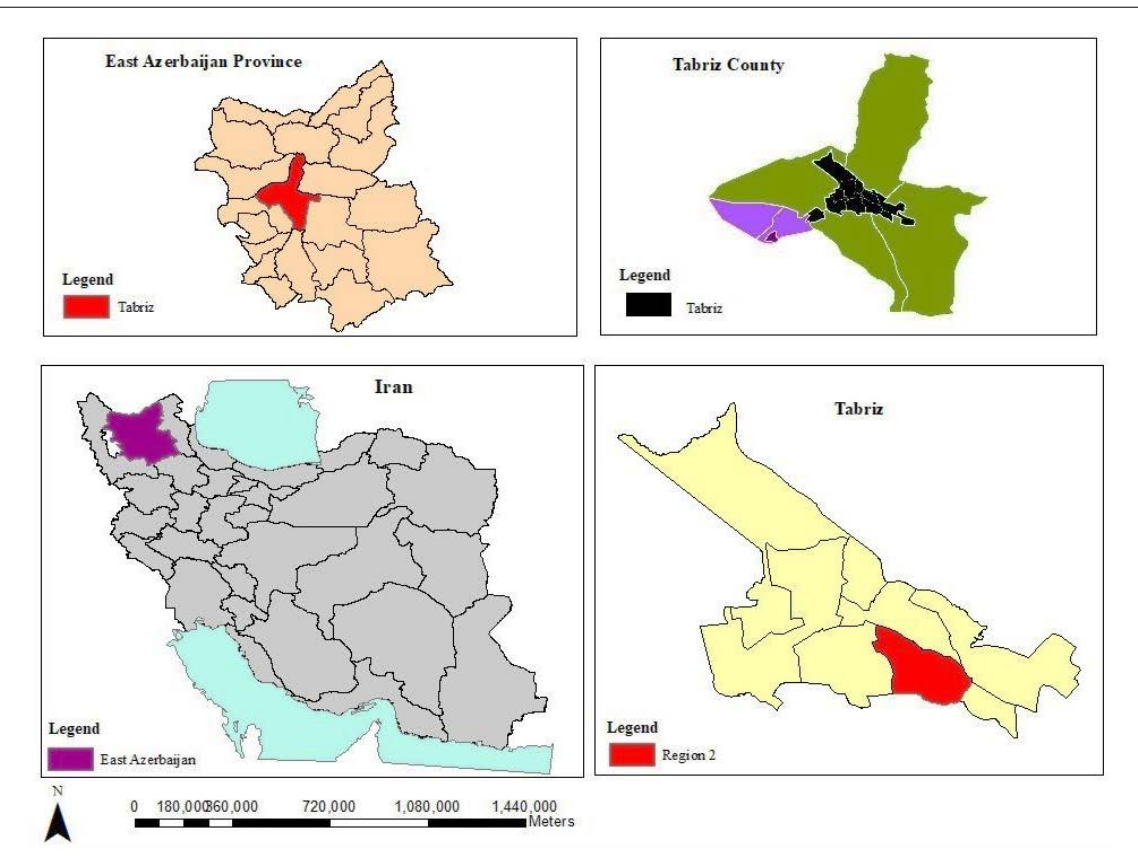

Figure 1: Location of the Tabriz Region 2

Source: The authors 


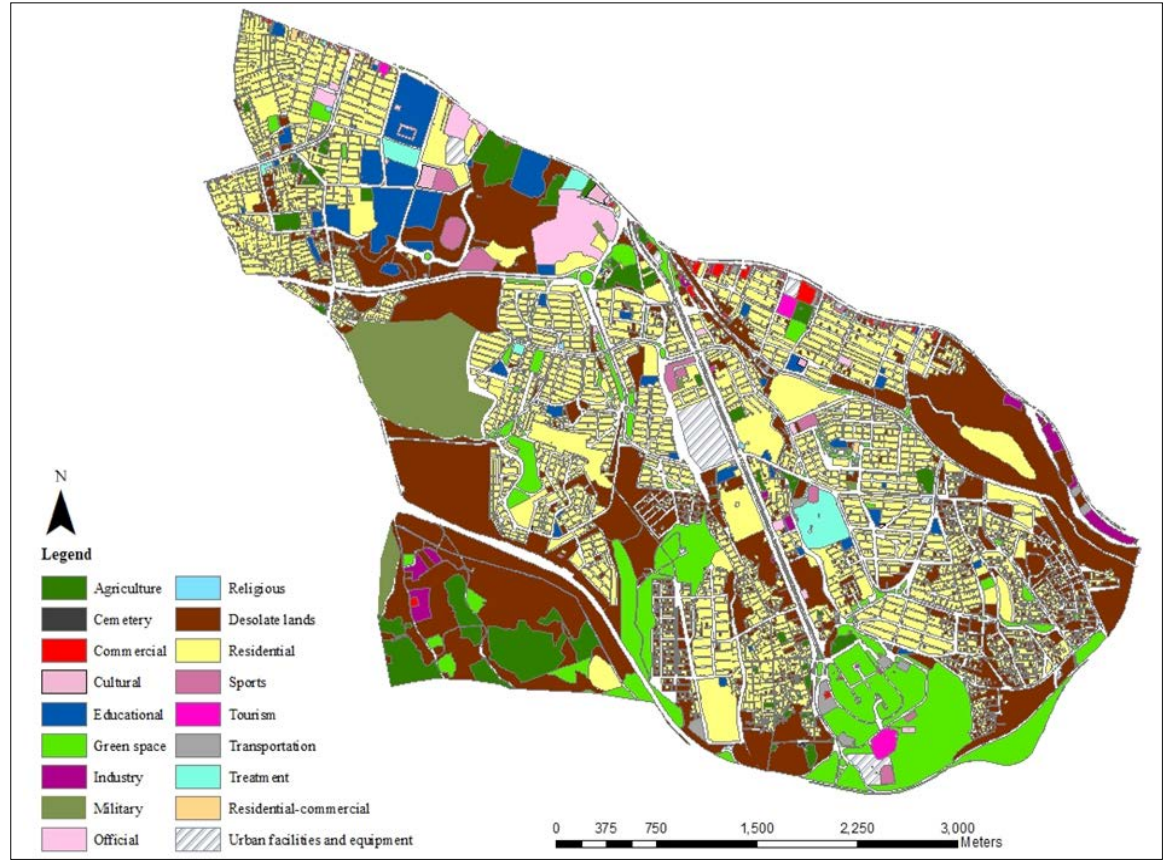

Figure 2: Land uses in Region 2

Source: The authors

\section{RESEARCH METHODS}

This research identified key influential factors that affect neighbourhoodbased management in Tabriz Region 2, Iran. A qualitative research design was used, in which structured questionnaire surveys enabled researchers to generalise their findings from a group of experts' consensus (Brady, 2015: 6). The research was based on the Delphi technique, and the survey data were obtained from two rounds. In Round 1, extracted from the open-ended questionnaire and extant literature, 48 initial items were identified in four components (participation, equity, accountability, and transparency) as factors affecting neighbourhood-based management, based on the components of good urban governance. In Round 2, these items were set as the variables in the Delphi-matrix questionnaire to calculate relationships between variables, using crossimpact analysis (CIA) (Okoli \& Pawlowski, 2004: 16). A cross-impact analysis (Bañuls \& Turoff, 2011: 1579) was used, because variables could be measured on a Likert scale (Clayton, 1997: 373), analysed and then ranked directly and indirectly on the basis of influence and dependence. The variables with the highest score had the most influence on the realisation of neighbourhood-based management.

\subsection{Sampling and expert panel selection}

Delphi sample sizes depend more on group dynamics in reaching consensus than on their statistical power (Okoli \& Pawlowski, 2004: 19). Using a nonprobability snowball sampling method (Bhattacherjee, 2012: 70), 60 experts were invited to participate in the Delphi survey. Snowball sampling was used to ensure that invited participants met the inclusion criteria, namely that all participants were required to be registered for, or already obtained a $\mathrm{PhD}$ qualification in urban studies from an academic institution in the study area. The invited participants were either academic professors in urban planning $(\mathrm{n}=20), \mathrm{PhD}$ candidates in urban planning known to the professors $(n=30)$, or urban managers employed in the study area $(n=10)$. Twenty experts responded to the first round and 40 to the second. In the Delphi process, general rulesof-thumb indicate that $15-30$ people for a homogeneous population (that is, experts coming from the same discipline such as, for example, urban planners) are generally considered to be sufficient to enable consensus to be achieved (Clayton, 1997: 378).

\subsection{Data collection}

Using the Delphi technique, data were collected from two survey rounds between 7 July and 29 October 2018. In Round 1, an open-ended questionnaire was distributed among the professionals and executives via email to state their views on the question: What are the most important factors that affect the future formation of neighbourhoodbased management in the four areas of participation, equity, accountability, and transparency?

In Round 2, participants were asked to independently apply weights to items in a Delphi questionnaire matrix of 48 statements, across 48 variables, using a 4-point Likert scale to determine the influence of each variable in the row on the statement in the column.

\subsection{Analysis and interpretation of the data}

To extract and identify the initial factors affecting neighbourhoodbased management, thematic data analysis was used to group 81 statements by participants, as well as reviews on the articles and writings published under the four areas of 'participation', 'equity', 'accountability', and 'transparency' (Braun \& Clarke, 2006: 87; Brady, 2014: 4). Once all the responses in the data set were grouped and reduced, labels could be generated for 48 factors identified as the initial factors affecting neighbourhood-based management, based on the components of urban governance.

MICMAC (the specialist software of futures studies) was used to do a cross-impact analysis of the initial factors, by calculating the relationship between variables in a $48 \times 48$ matrix. Cross-impact analysis is used in Delphi studies and allows for possible future scenarios and their interpretation, in order to answer a number of research questions 
on different subjects such as the future of a particular industrial sector (Bañuls \& Turoff, 2011: 1579). Items in the matrix were weighted (scored) on a 4-point Likert scale were $0=$ no influence, 1 = weak influence, 2 = moderate influence, and 3 = strong influence. Only one score for each item (as labelled) was considered to determine the influence of each variable in the row on the statement in the column. According to Clayton (1997: 373), 4-point scales produce stable findings in Delphi studies.

To identify the key influential factors that affect neighbourhood-based management, the 48 initial item scores from the cross-impact analysis were ranked directly and indirectly on the basis of influence and dependence. Thus, the variables with the highest score had the most influence on the realisation of neighbourhood-based management, based on the components of good urban governance in the Tabriz Region 2. They were then classified according to their location in the influence/dependence map of the variables (see Figures 3 and 4). Finally, 17 out of 48 factors were selected as the key factors.

\subsection{Limitations}

The selection of a small expert panel might have introduced its own bias into the research. Findings of this study are limited to the research area and cannot, therefore, be generalised across Iran or other countries.

\section{RESULTS AND DISCUSSION}

\subsection{Initial factors that affect neighbourhood-based management}

Table 3 shows a total of 48 items in four components (areas) identified

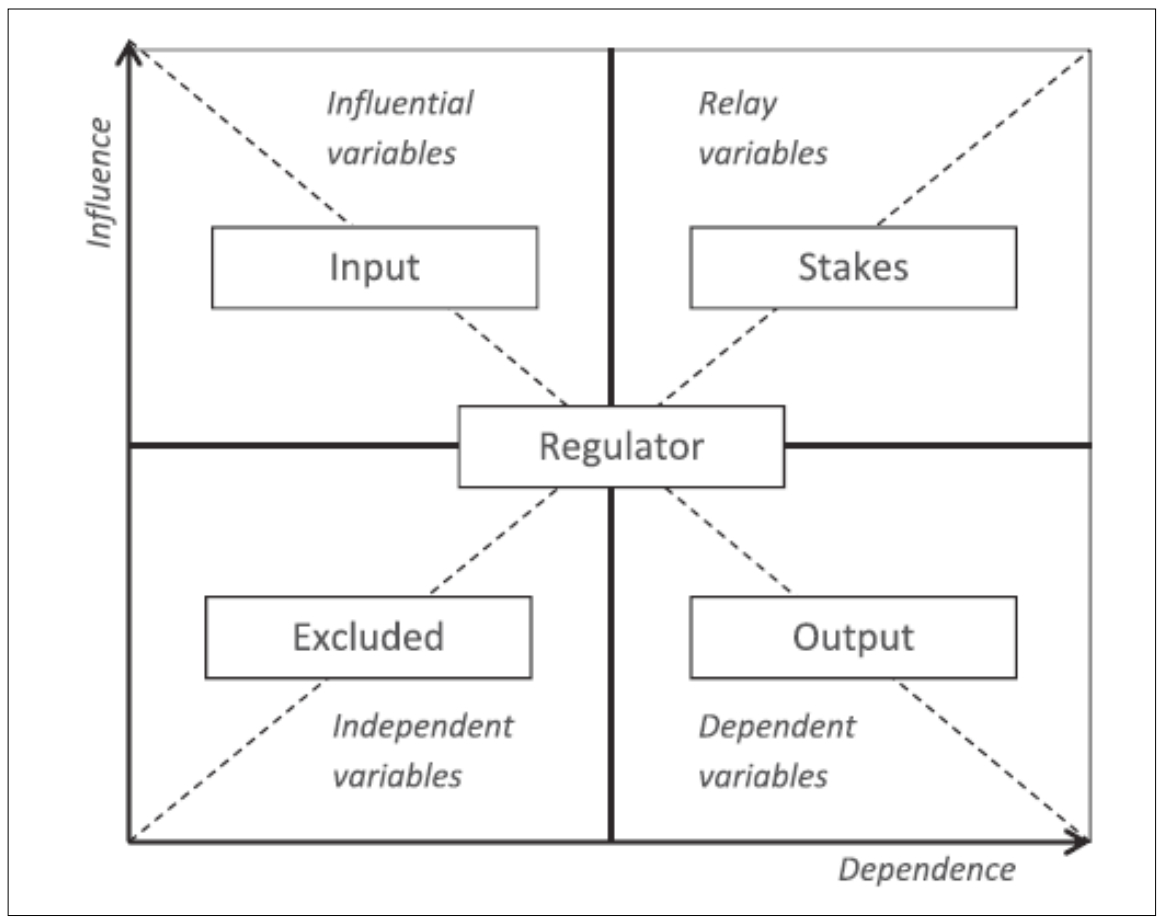

Figure 3: Influence and dependence diagram

Source: Villacorta et al., 2014: 21

Table 3: Initial factors affecting neighbourhood-based management

\begin{tabular}{|c|c|c|c|c|}
\hline Component & $\begin{array}{l}\text { Short } \\
\text { label }\end{array}$ & Description & Item & $\begin{array}{l}\text { Phrases in parentheses ( ) } \\
\text { represent items developed for } \\
\text { this research }\end{array}$ \\
\hline \multirow{12}{*}{ 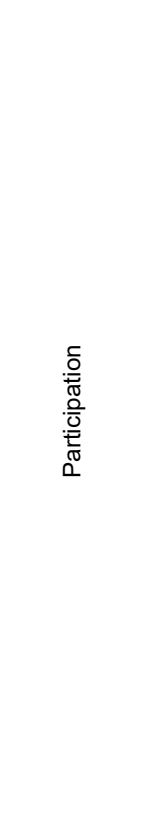 } & ROT-DV & $\begin{array}{l}\text { A reform of the top-down view of the planners and designers through the } \\
\text { inclusion of the local people in the decision-making process }\end{array}$ & $\begin{array}{l}\text { A reform of the } \\
\text { top-down view }\end{array}$ & (The down-top view) \\
\hline & $\mathrm{CP}$ & $\begin{array}{l}\text { Emphasis on human resources and social capital and the collective } \\
\text { participation of the neighbourhood residents }\end{array}$ & Collective participation & (Empowerment) \\
\hline & BO & $\begin{array}{l}\text { Improving the conditions for all people and promoting the resources and } \\
\text { opportunities for them }\end{array}$ & Building opportunity & (Creating a platform for activities) \\
\hline & MG & $\begin{array}{l}\text { Expansion of the representation and participation of traditionally } \\
\text { marginalised groups in the decision process on issues that affect their lives }\end{array}$ & Marginalised groups & $\begin{array}{l}\text { (Paying attention to marginalised } \\
\text { groups) }\end{array}$ \\
\hline & NGOs & $\begin{array}{l}\text { Welcoming the real involvement of local institutions and NGOs in the area } \\
\text { of decision and support for the direct participation of the local people }\end{array}$ & NGOs & $\begin{array}{l}\text { (Increasing a sense of } \\
\text { responsibility) }\end{array}$ \\
\hline & Pr. & Making responsible planners for the public proposals and feedback & Planners & (A poll) \\
\hline & EOPV & $\begin{array}{l}\text { Report on the how and degree of the effect of the participants' views on } \\
\text { making the change in results }\end{array}$ & $\begin{array}{l}\text { The effect of the } \\
\text { participants' views }\end{array}$ & (Holding meetings) \\
\hline & PV & $\begin{array}{l}\text { The optimal use of people's views in a variety of formats, including } \\
\text { criticism, proposal, complaint, appreciation and thanks, in order to reach a } \\
\text { common understanding with the aim of reforming and upgrading }\end{array}$ & People's views & (Communication action) \\
\hline & CAP & $\begin{array}{l}\text { Creating a platform for the formation of social organisations, associations } \\
\text { and popular groups, strengthening of syndicates, guilds and intermediary } \\
\text { organisations }\end{array}$ & Creating a platform & (Institutionalising monitoring) \\
\hline & St. & $\begin{array}{l}\text { Setting up a statement for planning and designing the neighbourhood by } \\
\text { the people, with the aim of identifying the specific identity of the site }\end{array}$ & Statement & (Cooperation in local projects) \\
\hline & LC & Implementing local projects by local contractors & Local contractors & (Local contracting) \\
\hline & Dn. & $\begin{array}{l}\text { Improvement to the neighborhood's environment by the people, including } \\
\text { plant maintenance, separation and collection of waste, and so on. }\end{array}$ & Delegation & $\begin{array}{l}\text { (Assigning neighbourhood affairs } \\
\text { to the citizens themselves) }\end{array}$ \\
\hline
\end{tabular}


Table 3: Continued.

\begin{tabular}{|c|c|c|c|c|}
\hline \multirow{12}{*}{ 言 } & le. & The people's access to social, physical and virtual infrastructure & Infrastructure & (Distribution of opportunities) \\
\hline & Se. & $\begin{array}{l}\text { The same distribution of services based on the needs and preferences of } \\
\text { the residents, and service standards }\end{array}$ & Services & $\begin{array}{l}\text { (Reducing social inequalities in } \\
\text { the community) }\end{array}$ \\
\hline & $\mathrm{N}-\mathrm{D}$ & Non-discriminatory approaches in shaping urban space & Non-discrimination & (Decision-making processes) \\
\hline & Fs. & $\begin{array}{l}\text { Equal access to health facilities, green space, quality of basic public } \\
\text { services, and so on. }\end{array}$ & Facilities & $\begin{array}{l}\text { (Fair distribution of resources } \\
\text { and benefits) }\end{array}$ \\
\hline & Res. & $\begin{array}{l}\text { Participatory tools for residents to contribute to their destiny (balance in the } \\
\text { distribution of resources, facilities or life exposed to environmental damage) }\end{array}$ & Resources & (Participatory tools) \\
\hline & C-BD & $\begin{array}{l}\text { Equal distribution of the cost and benefits of urban development for } \\
\text { all citizens }\end{array}$ & $\begin{array}{l}\text { Cost-benefit } \\
\text { distribution }\end{array}$ & $\begin{array}{l}\text { (Struggling against environmental } \\
\text { injustices) }\end{array}$ \\
\hline & $\mathrm{PI}$ & $\begin{array}{l}\text { The distribution of resources and their allocation, taking into account the } \\
\text { public interest, the needs and entitlement of citizens }\end{array}$ & Public interest & (Poverty alleviation) \\
\hline & EOy & $\begin{array}{l}\text { Equal access to opportunities, resources, facilities, and information for all } \\
\text { (in contrast to the rents of specific groups of power) }\end{array}$ & Equal opportunity & (Equal opportunity) \\
\hline & Sn. & Increasing the general satisfaction & Satisfaction & (Political stability of urban society) \\
\hline & Wn. & $\begin{array}{l}\text { Establishing and developing centres for women's activities in the urban } \\
\text { areas, by activating social institutions }\end{array}$ & Women & $\begin{array}{l}\text { (Encouraging the presence of } \\
\text { women in the community) }\end{array}$ \\
\hline & As. & $\begin{array}{l}\text { Increasing gender awareness and competition between men and women in } \\
\text { both public political and specialised areas of urban planning }\end{array}$ & Awareness & $\begin{array}{l}\text { (Paying special attention } \\
\text { to women) }\end{array}$ \\
\hline & OW & $\begin{array}{l}\text { Paying attention to obstacles to women's inclusion in urban life for their } \\
\text { participation in urban planning, design, and management }\end{array}$ & Obstacles to women & (Women's empowerment) \\
\hline \multirow{12}{*}{ 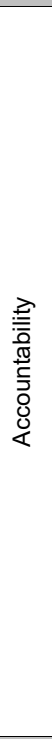 } & Ee. & $\begin{array}{l}\text { Identifying elites at the neighbourhood level and utilising their abilities in } \\
\text { related (cultural, artistic, sport, scientific) areas }\end{array}$ & Elites & (Identifying elites) \\
\hline & Fn. & $\begin{array}{l}\text { The familiarisation of citizens with the programmes and activities of } \\
\text { the municipality and neighbourhood management to increase their } \\
\text { collaboration }\end{array}$ & Familiarisation & $\begin{array}{l}\text { (Advertising and informing at the } \\
\text { neighbourhood level) }\end{array}$ \\
\hline & In. & $\begin{array}{l}\text { Strengthening people's interaction with the municipality and neighbourhood } \\
\text { management, and vice versa, through building trust in citizens }\end{array}$ & Interaction & (Encouraging public participation) \\
\hline & MS & Public meeting sessions to explain the actions, and informing citizens & Meeting sessions & $\begin{array}{l}\text { (Providing information on } \\
\text { work progress) }\end{array}$ \\
\hline & SP & $\begin{array}{l}\text { Identifying and solving neighbourhood problems and providing information } \\
\text { on their realisation }\end{array}$ & Solving problems & $\begin{array}{l}\text { (Tackling neighbourhood issues } \\
\text { and problems) }\end{array}$ \\
\hline & BR & $\begin{array}{l}\text { Lack of the arbitrary and irresponsible activities in the management of city } \\
\text { and urban neighbourhoods }\end{array}$ & Being responsible & $\begin{array}{l}\text { (Neighbourhood managers' } \\
\text { straightforwardness) }\end{array}$ \\
\hline & $A D$ & $\begin{array}{l}\text { The accountability of city and neighbourhood managers to their duties and } \\
\text { accepting them as a principle }\end{array}$ & Accepting duties & (Carrying out promises) \\
\hline & $\mathrm{N}-\mathrm{N}$ & Non-nepotism in the administrative activities of the neighbourhood & Non-nepotism & (Non-nepotism and lack of bribery) \\
\hline & CR & A convincing response of neighbourhood managers to the people & Convincing response & (Answering people's questions) \\
\hline & MC & Impacting citizens or groups of power in neighbourhood decisions & Measuring corruption & (Measuring corruption) \\
\hline & Ae. & $\begin{array}{l}\text { The adherence of the people to the laid-down rules and regulations and } \\
\text { adherence of neighbourhood management to the rights of citizens }\end{array}$ & Adherence & (Adherence) \\
\hline & Ey. & The obedience of neighbourhood management to equality against the law & Equality & (Lack of discrimination and bias) \\
\hline \multirow{12}{*}{ 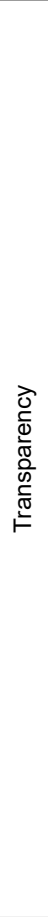 } & Pe. & $\begin{array}{l}\text { The monthly reporting of activities of neighbourhood organisation } \\
\text { and management }\end{array}$ & Performance & (Monthly performance reports) \\
\hline & Pn. & $\begin{array}{l}\text { The reporting of the degree of the performance realisation of } \\
\text { neighbourhood managers }\end{array}$ & Progression & (A progress report) \\
\hline & EO & $\begin{array}{l}\text { Expressing opinion of the residents on the performance of } \\
\text { neighbourhood management }\end{array}$ & Expressing & Opinion (Citizens' attitudes) \\
\hline & EP & $\begin{array}{l}\text { Electronically performing processes and increasing the speed of operation } \\
\text { and quality of work }\end{array}$ & $\begin{array}{l}\text { Electronically } \\
\text { performing }\end{array}$ & (Online monitoring) \\
\hline & WR & $\begin{array}{l}\text { Accountability to requests and questions received from the public in writing } \\
\text { and documented by law }\end{array}$ & Written response & (Written responsibility) \\
\hline & Re. & The people's access to the laid-down rules and documents & Rules & $\begin{array}{l}\text { (Access to the rules } \\
\text { and documents) }\end{array}$ \\
\hline & $\mathrm{FI}$ & $\begin{array}{l}\text { Planning and organising an information transparency system, including the } \\
\text { access to, and free dissemination of information }\end{array}$ & Free information & $\begin{array}{l}\text { (An information } \\
\text { transparency system) }\end{array}$ \\
\hline & SC & $\begin{array}{l}\text { The establishment of specific criteria for the categorisation of approvals } \\
\text { and correspondences for the avoidance of unnecessarily knowing } \\
\text { confidential information }\end{array}$ & Specific criteria & (Honesty in giving information) \\
\hline & Dg. & $\begin{array}{l}\text { The preparation of documents, evidence of the evolution and } \\
\text { implementation of activities to avoid duplication and empiricism in } \\
\text { implementing projects }\end{array}$ & Documenting & (Documentation of information) \\
\hline & Bt. & Providing annual budget information for citizens & Budget & $\begin{array}{l}\text { (Budgeting and } \\
\text { financial forecasting) }\end{array}$ \\
\hline & IW & $\begin{array}{l}\text { Inserting the minimum and maximum monthly wages at the Internet } \\
\text { site, indicating the suitability of the qualifications of individuals and } \\
\text { their performance }\end{array}$ & Inserting wages & (Clarification of pay slips) \\
\hline & FS & $\begin{array}{l}\text { The preparation of financial statements from the financial status and } \\
\text { performance of neighbourhood management }\end{array}$ & Financial statements & (Financial reporting) \\
\hline
\end{tabular}


and short-labelled as the initial factors that affect neighbourhoodbased management, based on the components of urban governance in the Tabriz Region 2. For each of the four components (areas), 12 items were identified and described. It is important to note that the phrases in parentheses represent the items developed for this study.

\subsection{Matrix results}

Figure 3 and Table 4 show the relationship results of the matrix data after rotation. In the matrix, the cross-impacts were of $99 \%$ utility after two rotations of data, indicating the high validity of the questionnaire and its responses.

Table 4: Initial data analysis of cross-impact matrix

\begin{tabular}{|l|c|}
\hline Indicator & Value \\
\hline Matrix size & 48 \\
\hline Number of interactions & 2 \\
\hline Number of zeros & 48 \\
\hline Number of ones & 83 \\
\hline Number of twos & 2149 \\
\hline Number of threes & 24 \\
\hline Total & 2256 \\
\hline Fillrate & $97.91 \%$ \\
\hline
\end{tabular}

Table 4 shows that the matrix fill rate was $97.91 \%$. From a total of 2256 evaluable relationships in the matrix, 48, 83, two, 149 and 24 relationships had $0(2.12 \%)$ (no influence), one $(3.68 \%)$ (weak influence), two (95.26\%) (moderate influence), and three $(1.06 \%)$ (strong influence), respectively. Based on the crossimpact analysis of relationships in Figure 3 and Table 4, it is possible to implement a new approach to neighbourhood-based management, emphasising the components of good urban governance in the planning and management of the metropolis of Tabriz, using futures studies (predictions).

Figure 4 shows the classification of the initial items affecting neighbourhood-based management, based on the components of good urban governance in the Tabriz Region 2, classified according to their location in the influence/ dependence map of the variables. The results show that the majority of the factors link to the relay variables (simultaneously have a very high influence and dependence) and dependent variables (have a low influence and high dependence) quadrants.

Results show that, among the initial variables, only 'the improvement of the neighbourhood's environment by the people, including plant maintenance, separation and collection of waste', and so on were classified as Influential variables (Input). These variables are more influential, less dependent, and considered the most critical variables, because system changes are dependent on them. Managing and controlling these items is crucial, because any change in these items causes a change in the functioning of the system (Fanni \& Kāzemi, 2016: 18).

Relay variables (Stakes) have a very high influence and dependence simultaneously. The condition of these variables is accompanied by instability, since each operation and change in them cause changes in other variables. Any change in the system causes changes in these items and their influence. These variables explain the key factors of the system. Since these variables have high significance and uncertainty, development scenarios are based on these variables (Fanni \& Kāzemi, 2016: 18). Among the initial variables, 16 were part of the Relay variables (Stakes) (strategic variables): equal access to opportunities, resources, facilities, and information for all (in contrast to the rents of specific groups of power); a reform of the top-down view of the planners and designers through the inclusion of the local people in the decision-making process; the same distribution of services based on the needs and preferences of the residents, and service standards; the familiarisation of citizens with the programmes and activities of the municipality and neighbourhood management to increase their collaboration; public meeting sessions to explain the actions, and informing citizens; non-nepotism in the administrative activities of the neighbourhood; lack of arbitrary and irresponsible activities in the management of city and urban neighbourhoods; reporting the degree of the performance realisation of neighbourhood managers; people's access to social, physical and virtual infrastructure; equal access to health facilities, green space, quality of basic public services, and so on; participatory tools for residents to contribute to their destiny (balance in the distribution of resources, facilities or life exposed to environmental damage); strengthening people's interaction with the municipality and neighbourhood management,

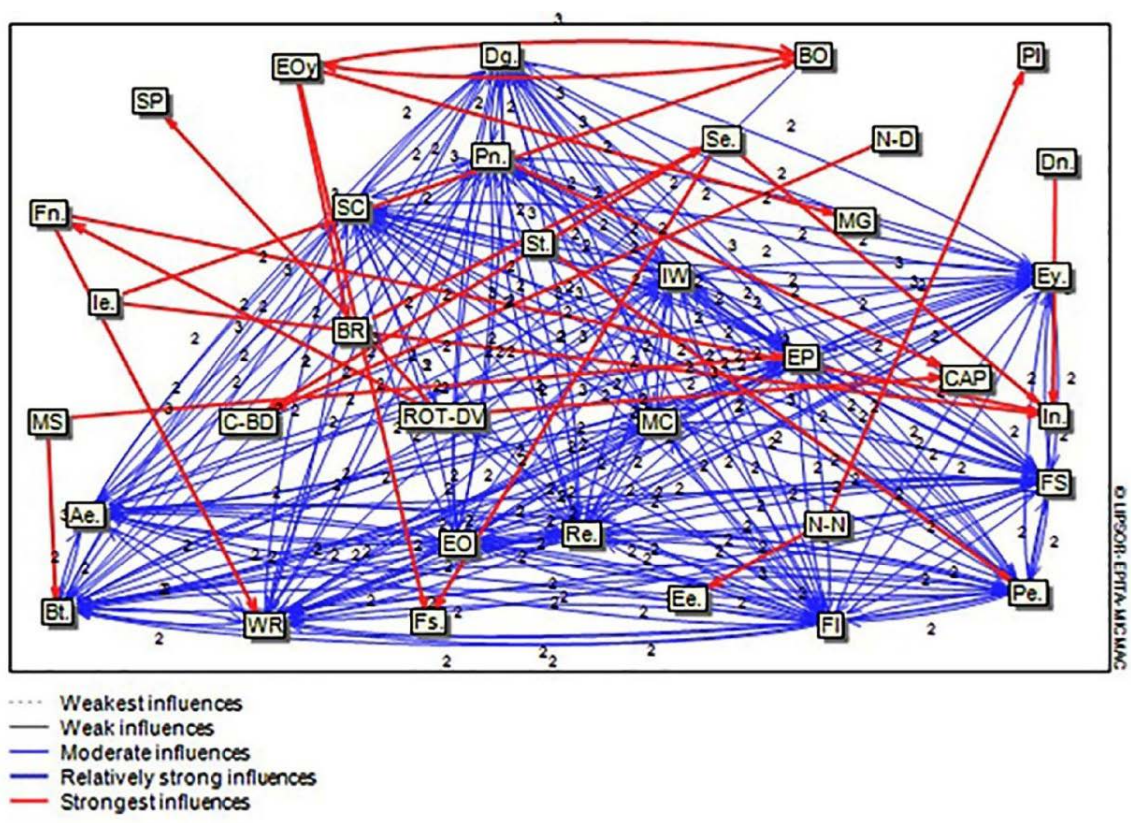

Figure 4: Direct relationships between variables (weak to strong) 
and vice versa, through building trust in citizens; identifying and solving neighbourhood problems and providing information on their realisation; impacting citizens or groups of power in neighbourhood decisions; the obedience of neighbourhood management to equality against the law; electronically performing processes, and increasing the speed of operation and quality of work.

Items in the Dependent variables (Output) quadrant have a low influence and high dependence. The dependent items play the role of the system output, that is, the result of the events occurring in the system. In fact, the how and performance of these variables depend on the occurrence of each scenario, as well as changes made in other variables (Fanni \& Kāzemi, 2016: 18). In the possible realisation of neighbourhoodbased management, based on the components of good urban governance in the Tabriz Region 2, variables such as welcoming the real involvement of local institutions and NGOs in the area of decision and support for the direct participation of the local people; accountability of city and neighbourhood managers to their duties and accepting them as a principle; monthly reporting of activities of neighbourhood organisation and management; creating a platform for the formation of social organisations, associations and popular groups; strengthening syndicates, guilds and intermediary organisations; expressing opinion of the residents on the performance of neighbourhood management; distribution of resources and their allocation, taking into account the public interest, the needs and entitlement of citizens; paying attention to obstacles to women's inclusion in urban life for their participation in urban planning, design, and management; identifying elites at neighbourhood level and utilising their abilities in related areas (cultural, artistic, sport, scientific); providing annual budget information for citizens; increasing gender awareness and competition between men and women in both public political and specialised areas of urban planning, and expansion of the representation and participation of traditionally marginalised groups in the decision process on issues that affect their lives, are the result of a set of influential factors.

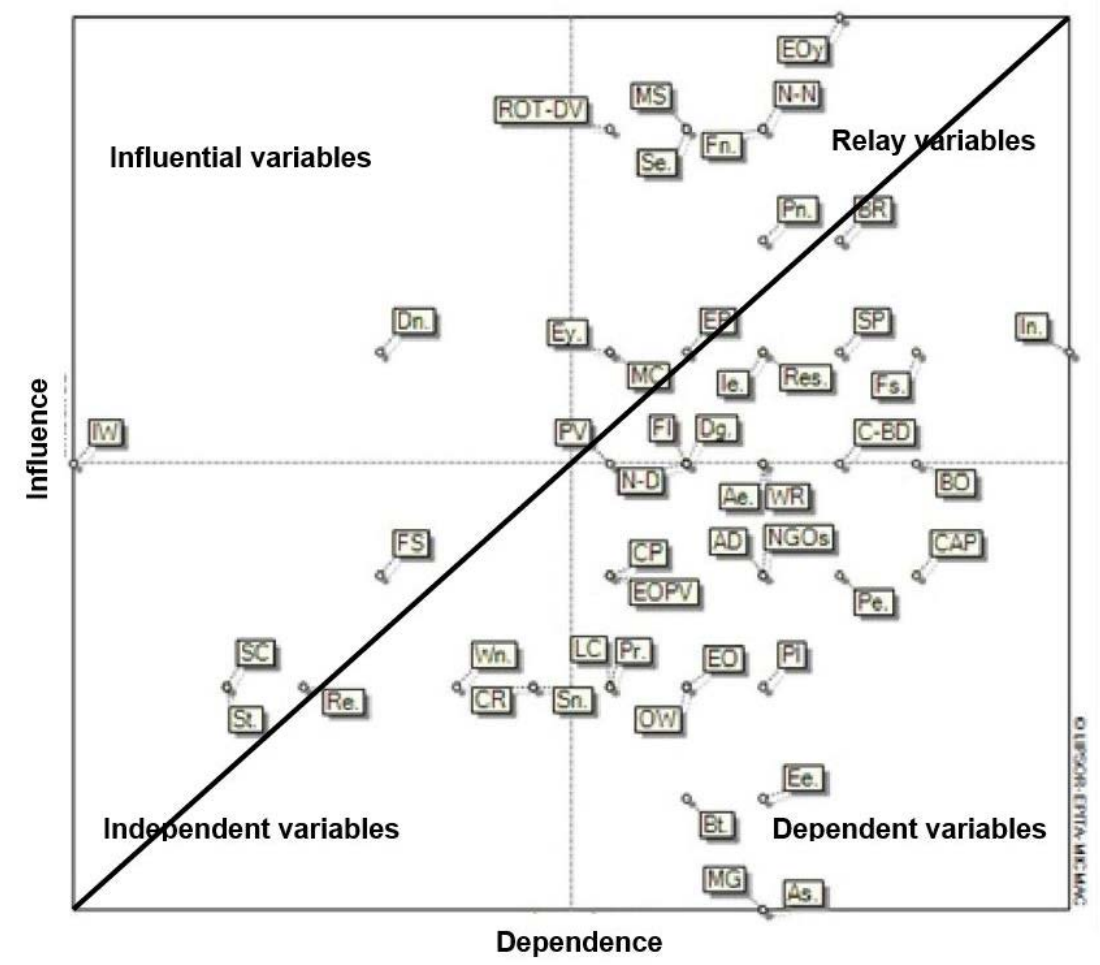

Figure 5: Classification of items based on direct influence/dependence map

Moreover, among the dependent variables, factors such as planning and organising an information transparency system, including the access to and free dissemination of information; non-discriminatory approaches in shaping urban space; improving the conditions for all people and promoting the resources and opportunities for them; the optimal use of people's views in a variety of formats, including criticism, proposal, complaint, appreciation, and thanks, in order to reach a common understanding with the aim of reforming and upgrading; the preparation of documents, evidence of the evolution and implementation of activities to avoid duplication and empiricism in implementing projects; people's adherence to the laid-down rules and regulations and neighbourhood management's adherence to the rights of citizens; accountability to requests and questions received from the public in writing and documented by law; equal distribution of the cost and benefits of urban development for all citizens; report on the how and degree of the effect of the participants' views on making the change in results; emphasis on human resources and social capital, and collective participation of the neighbourhood residents; making responsible planners for the public proposals and feedback, and implementing local projects by local contractors, located near the centre of gravity of the map and known as regulators, can be applied as effective factors in system stability and realisation of neighbourhoodbased management, based on the components of good urban governance in the Tabriz Region 2.

Autonomous variables (Excluded) are excluded and have a low dependence on other variables. These factors are independent of other variables. To promote and improve these factors, they must be identified (Fanni \& Kāzemi, 2016: 18). Factors such as the preparation of financial statements from the financial status and performance of neighbourhood management; people's access to the laid-down 
rules and documents; setting up a statement for planning and designing the neighbourhood by the people, with the aim of identifying the specific identity of the site; establishing specific criteria for the categorisation of approvals and correspondences for the avoidance of unnecessarily knowing confidential information, and establishing and developing centres for women's activities in the urban areas, by activating social institutions, were placed in this category. Furthermore, among the autonomous variables, variables such as increasing the general satisfaction; a convincing response of neighbourhood managers to the people, and inserting the minimum and maximum monthly wages at the Internet site, indicating the suitability of the qualifications of individuals and their performance (regulators), can be applied as effective factors in system stability and realisation of neighbourhoodbased management, based on the components of good urban governance in the Tabriz Region 2.

\subsection{Ranking of initial factors that affect neighbourhood-based management}

Table 5 shows the ranking of the ratings from the cross-impact analysis on how the initial factors had a direct/ indirect influence and dependence on each other. The items with the highest score had the most influence on the realisation of neighbourhoodbased management, based on the components of good urban governance in the Tabriz Region 2.

\subsection{Ranking of the key factors affecting neighbourhood- based management}

Table 6 shows the 17 variables (after direct and indirect influence rotation) extracted as the key factors affecting neighbourhood-based management, based on the components of good urban governance in the Tabriz Region 2. These 17 factors play the most important role in the future state of good neighbourhood-based management. The results show that the driving force of accountability

Table 5: Rating of the direct and indirect influence and dependence of the factors that affect neighbourhoodbased management on each other

\begin{tabular}{|c|c|c|c|c|c|c|c|c|}
\hline Rank & Label & $\begin{array}{c}\text { Direct } \\
\text { influence }\end{array}$ & Label & $\begin{array}{c}\text { Direct } \\
\text { dependence }\end{array}$ & Label & $\begin{array}{c}\text { Indirect } \\
\text { influence }\end{array}$ & Label & $\begin{array}{c}\text { Indirect } \\
\text { dependence }\end{array}$ \\
\hline 1 & EOy & 217 & In. & 220 & EOy & 217 & In. & 219 \\
\hline 2 & ROT-DV & 215 & $\mathrm{BO}$ & 215 & ROT-DV & 215 & $\mathrm{BO}$ & 215 \\
\hline 3 & Se. & 215 & CAP & 215 & Se. & 215 & Fs. & 215 \\
\hline 4 & Fn. & 215 & Fs. & 215 & Fn. & 215 & CAP & 215 \\
\hline 5 & MS & 215 & C-BD & 213 & MS & 215 & CAP & 213 \\
\hline 6 & $\mathrm{~N}-\mathrm{N}$ & 215 & EOy & 213 & $\mathrm{~N}-\mathrm{N}$ & 215 & $\mathrm{BR}$ & 213 \\
\hline 7 & BR & 213 & SP & 213 & $\mathrm{BR}$ & 213 & $\mathrm{SP}$ & 213 \\
\hline 8 & Pn. & 213 & BR & 213 & Pn. & 213 & C-BD & 213 \\
\hline 9 & Dn. & 211 & Pe. & 213 & le. & 211 & Pe. & 213 \\
\hline 10 & le. & 211 & MG & 211 & Fs. & 211 & $\mathrm{PI}$ & 211 \\
\hline 11 & Fs. & 211 & NGOs & 211 & Res. & 211 & Fn. & 211 \\
\hline 12 & Res. & 211 & le. & 211 & In. & 211 & MG & 211 \\
\hline 13 & In. & 211 & Res & 211 & SP & 211 & Ee. & 211 \\
\hline 14 & SP & 211 & $\mathrm{PI}$ & 211 & $\mathrm{MC}$ & 211 & WR & 211 \\
\hline 15 & $\mathrm{MC}$ & 211 & As & 211 & Ey. & 211 & NGOs & 211 \\
\hline 16 & Ey. & 211 & Ee. & 211 & EP & 211 & le. & 211 \\
\hline 17 & EP & 211 & Fn. & 211 & Dn. & 210 & Res. & 211 \\
\hline 18 & $\mathrm{BO}$ & 208 & $A D$ & 211 & $\mathrm{BO}$ & 208 & As. & 211 \\
\hline 19 & PV & 208 & $\mathrm{~N}-\mathrm{N}$ & 211 & WR & 208 & $A D$ & 211 \\
\hline 20 & $\mathrm{~N}-\mathrm{D}$ & 208 & $\mathrm{Ae}$. & 211 & PV & 208 & $\mathrm{~N}-\mathrm{N}$ & 211 \\
\hline 21 & C-BD & 208 & Pn. & 211 & Ae. & 208 & Ae. & 211 \\
\hline 22 & $\mathrm{Ae}$. & 208 & WR & 211 & $\mathrm{~N}-\mathrm{D}$ & 208 & Pn. & 211 \\
\hline 23 & WR & 208 & Se. & 208 & C-BD & 208 & Bt. & 208 \\
\hline 24 & $\mathrm{FI}$ & 208 & $\mathrm{~N}-\mathrm{D}$ & 208 & IW & 208 & Se. & 208 \\
\hline 25 & Dg. & 208 & OW & 208 & Dg. & 208 & $\mathrm{~N}-\mathrm{D}$ & 208 \\
\hline 26 & IW & 208 & MS & 208 & $\mathrm{FI}$ & 208 & $\mathrm{FI}$ & 208 \\
\hline 27 & $\mathrm{CP}$ & 206 & EO & 208 & $A D$ & 206 & MS & 208 \\
\hline 28 & NGOs & 206 & EP & 208 & NGOs & 206 & OW & 208 \\
\hline 29 & EOPV & 206 & $\mathrm{FI}$ & 208 & $\mathrm{CP}$ & 206 & EP & 208 \\
\hline 30 & CAP & 206 & Dg. & 208 & CAP & 206 & Dg. & 208 \\
\hline 31 & $A D$ & 206 & Bt. & 208 & EOPV & 206 & EO & 208 \\
\hline 32 & Pe. & 206 & ROT-DV & 206 & Pe. & 206 & PV & 206 \\
\hline 33 & FS & 206 & $\mathrm{CP}$ & 206 & FS & 206 & Pr. & 206 \\
\hline 34 & Pr. & 204 & Pr. & 206 & Sn. & 204 & $\begin{array}{l}\text { ROT- } \\
\text { DV }\end{array}$ & 206 \\
\hline 35 & St. & 204 & EOPV & 206 & LC & 204 & LC & 206 \\
\hline 36 & LC & 204 & PV & 206 & Wn. & 204 & Ey. & 206 \\
\hline 37 & $\mathrm{PI}$ & 204 & LC & 206 & Re. & 204 & $\mathrm{MC}$ & 206 \\
\hline 38 & Sn. & 204 & $\mathrm{MC}$ & 206 & SC & 204 & EOPV & 206 \\
\hline 39 & Wn. & 204 & Ey. & 206 & $\mathrm{PI}$ & 204 & $\mathrm{CP}$ & 206 \\
\hline 40 & OW & 204 & Sn. & 204 & St. & 204 & Sn. & 204 \\
\hline 41 & CR & 204 & CR & 204 & EO & 204 & CR & 204 \\
\hline 42 & EO & 204 & Wn. & 202 & OW & 204 & Wn. & 202 \\
\hline 43 & Re. & 204 & Dn. & 199 & Pr. & 204 & Dn. & 199 \\
\hline 44 & SC & 204 & $\mathrm{FS}$ & 199 & CR & 204 & FS & 199 \\
\hline 45 & Ee. & 202 & Re. & 197 & Bt. & 202 & Re. & 197 \\
\hline 46 & Bt. & 202 & St. & 195 & Ee. & 202 & St. & 195 \\
\hline 47 & MG & 199 & SC & 195 & As. & 200 & SC & 195 \\
\hline 48 & As. & 199 & IW & 190 & MG & 200 & IW & 191 \\
\hline
\end{tabular}

(eight factors) and then equity (five factors) will have the greatest role in the realisation of neighbourhoodbased management in the planning and management of the metropolis of Tabriz. This finding with regard to the key factors of accountability is in line with the result of Meškini et al.'s study (2013), which suggested that the components of effectiveness and accountability have played a greater role in shaping good urban governance in the management of the neighbourhood under study.

Table 6 shows that there were some displacements among the variables, once the indirect influences were taken into account. 
A big displacement also occurred for the variable "delegation".

The displacement and distribution of variables on the influence/ dependence map indicate the degree of stability or instability of a system. Figure 6 shows a model of stable and unstable systems. In stable systems, the distribution of the variables showed a 'L-form'; that is, some variables have a great influence and some have a great dependence. In unstable systems, the state is more complex than in stable systems; in these systems, the variables are distributed around the diagonal axis of the map (see Figure 5) (Na'imi \& Purmohammadi, 2016: 58).

Most of the variables have been distributed around the diagonal axis of the map (see Figures 4 and 5).

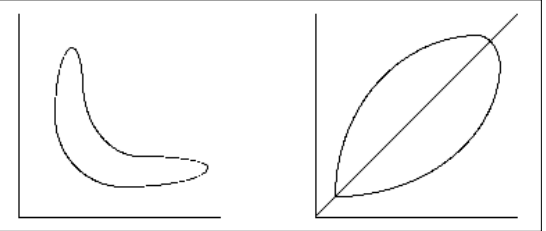

Figure 6: Model of stable (left) and unstable (right) systems

Source: Na'imi \&

Purmohammadi, 2016: 59

With the exception of a few limited factors that have been shown to have a great influence on the system, the other variables are almost identical to each other. This shows that the future state of neighbourhood-based management, based on a good urban governance system in the Tabriz Region 2, is not stable.

\section{CONCLUSION}

This research was conducted with the aim of identifying the most important effective factors (driving forces) and studying the how and degree of influence these factors have on affecting the feasibility of neighbourhood-based management, based on the components of good urban governance in the Tabriz Region 2. Using the intellectual foundation of futures studies, this research has a unique complexity and innovation and is the first scientific experience in the field of neighbourhood-based management, using futures studies.

In this research, 17 driving forces or key factors were identified: (1) A reform of the top-down view of the planners and designers through the

Table 6: Key factors affecting neighbourhood-based management

\begin{tabular}{|c|c|c|c|c|c|c|c|}
\hline \multirow[t]{2}{*}{ Factor } & \multirow[t]{2}{*}{ Area } & \multirow[t]{2}{*}{ Description } & \multirow{2}{*}{$\begin{array}{l}\text { Short } \\
\text { label }\end{array}$} & \multicolumn{2}{|c|}{ Score } & \multicolumn{2}{|c|}{ Rank } \\
\hline & & & & $\begin{array}{c}\text { Direct } \\
\text { influence }\end{array}$ & $\begin{array}{l}\text { Indirect } \\
\text { influence }\end{array}$ & $\begin{array}{l}\text { Direct } \\
\text { influence }\end{array}$ & $\begin{array}{l}\text { Indirect } \\
\text { influence }\end{array}$ \\
\hline Equal opportunity & (Equity) & $\begin{array}{l}\text { (1) Equal access to opportunities, resources, facilities, and } \\
\text { information for all (in contrast to the rents of specific groups } \\
\text { of power) }\end{array}$ & EOy & 217 & 217 & 1 & 1 \\
\hline $\begin{array}{l}\text { A reform of the } \\
\text { top-down view }\end{array}$ & (Participation) & $\begin{array}{l}\text { (2) A reform of the top-down view of the planners and designers } \\
\text { through the inclusion of the local people in the decision- } \\
\text { making process }\end{array}$ & ROT-DV & 215 & 215 & 2 & 2 \\
\hline Services & (Equity) & $\begin{array}{l}\text { (3) The same distribution of services based on the needs and } \\
\text { preferences of the residents, and service standards }\end{array}$ & Se. & 215 & 215 & 3 & 3 \\
\hline Familiarisation & (Accountability) & $\begin{array}{l}\text { (4) The familiarisation of citizens with the programmes and } \\
\text { activities of municipality and neighbourhood management to } \\
\text { increase their collaboration }\end{array}$ & Fn. & 215 & 215 & 4 & 4 \\
\hline Meeting sessions & (Accountability) & $\begin{array}{l}\text { (5) Public meeting sessions to explain the actions, and } \\
\text { informing citizens }\end{array}$ & MS & 215 & 215 & 5 & 5 \\
\hline Non-nepotism & (Accountability) & $\begin{array}{l}\text { (6) Non-nepotism in the administrative activities of } \\
\text { the neighbourhood }\end{array}$ & $\mathrm{N}-\mathrm{N}$ & 215 & 215 & 6 & 6 \\
\hline Being responsible & (Accountability) & $\begin{array}{l}\text { (7) Lack of the arbitrary and irresponsible activities in the } \\
\text { management of city and urban neighbourhood }\end{array}$ & $\mathrm{BR}$ & 213 & 213 & 7 & 7 \\
\hline Progression & (Transparency) & $\begin{array}{l}\text { (8) The reporting of the degree of the performance realisation of } \\
\text { neighbourhood managers }\end{array}$ & Pn. & 213 & 213 & 8 & 8 \\
\hline Delegation & (Participation) & $\begin{array}{l}\text { (9) The improvement of the neighbourhood's environment } \\
\text { by the people, including plant maintenance, separation and } \\
\text { collection of waste, and so on }\end{array}$ & Dn. & 211 & 210 & 9 & 17 \\
\hline Infrastructure & (Equity) & (10) People's access to social, physical and virtual infrastructure & le. & 211 & 211 & 10 & 9 \\
\hline Facilities & (Equity) & $\begin{array}{l}\text { (11) Equal access to health facilities, green space, quality of } \\
\text { basic public services, and so on }\end{array}$ & Fs. & 211 & 211 & 11 & 10 \\
\hline Resources & (Equity) & $\begin{array}{l}\text { (12) Participatory tools for residents to contribute to their } \\
\text { destiny (balance in the distribution of resources, facilities or life } \\
\text { exposed to environmental damage) }\end{array}$ & Res. & 211 & 211 & 12 & 11 \\
\hline Interaction & (Accountability) & $\begin{array}{l}\text { (13) Strengthening people's interaction with the municipality } \\
\text { and neighbourhood management, and vice versa, through } \\
\text { building trust in citizens }\end{array}$ & In. & 211 & 211 & 13 & 12 \\
\hline $\begin{array}{l}\text { Measuring } \\
\text { corruption }\end{array}$ & (Accountability) & $\begin{array}{l}\text { (15) Impacting citizens or groups of power in } \\
\text { neighbourhood decisions }\end{array}$ & MC & 211 & 211 & 15 & 14 \\
\hline Equality & (Accountability) & $\begin{array}{l}\text { (16) The obedience of neighbourhood management to equality } \\
\text { against the law }\end{array}$ & Ey & 211 & 211 & 16 & 15 \\
\hline $\begin{array}{l}\text { Electronically } \\
\text { performing }\end{array}$ & (Transparency) & $\begin{array}{l}\text { (17) Electronically performing processes and increasing the } \\
\text { speed of operation and quality of work }\end{array}$ & EP & 211 & 211 & 17 & 16 \\
\hline
\end{tabular}


inclusion of the local people in the decision-making process (Participation / participation in decision-making);

(2) The improvement of the neighborhood's environment by the people, including plant maintenance, separation and collection of waste, and so on (Participation / participation in intervention); (3) Equal access to opportunities, resources, facilities, and information for all (in contrast to the rents of specific groups of power) (Equity / social equity); (4) The same distribution of services based on the needs and preferences of the residents, and service standards (Equity / spatial equity); (5) People's access to social, physical and virtual infrastructure (Equity / spatial equity); (6) Equal access to health facilities, green space, quality of basic public services, and so on (Equity / environmental equity); (7) Participatory tools for residents to contribute to their destiny (balance in the distribution of resources, facilities or life exposed to environmental damage) (Equity / environmental equity); (8) The familiarisation of citizens with the programmes and activities of the municipality and neighbourhood management to increase their collaboration (Accountability / participatory accountability); (9) Public meeting sessions to explain the actions, and informing citizens (Accountability / functional accountability); (10) Non-nepotism in the administrative activities of the neighbourhood (Accountability / moral accountability); (11) Lack of the arbitrary and irresponsible activities in the management of city and urban neighbourhoods (Accountability

/ functional accountability);

(12) Strengthening people's interaction with the municipality and neighbourhood management, and vice versa, through building trust in citizens (Accountability / participatory accountability); (13) Identifying and solving neighbourhood problems and providing information on their realisation (Accountability / functional accountability); (14) Impacting citizens or groups of power in neighbourhood decisions (Accountability / legal accountability); (15) The obedience of neighbourhood management to equality against the law (Accountability / legal accountability); (16) The reporting of the degree of the performance realisation of neighbourhood managers (Transparency / functional transparency); (17) Electronically performing processes and increasing the speed of operation and quality of work (Transparency / administrative transparency).

As this research is a starting point for explaining an approach to futures studies in the field of neighbourhoodbased management, urban planners and all those who influence urban planning and management in Iran and other countries can use the results of this research to realise neighbourhood-based management, emphasising the components of good urban governance in the planning and management of their location. It is important that each location is unique. Thus, what works in one place may not work in another. Therefore, further research is required to identify the driving forces in the field of this research to meet the needs of the local area of other urban planners. To do so, one should use futures studies to accurately identify the driving forces or key effective factors by the realistic use of the capabilities of the community. The realisation of this approach requires a firm legal support, so that the status, duties and responsibilities of citizens and authorities at different levels are identified in a two-way, coordinated process. Doing so will create scenarios and formulate strategies for good urban governance, based on new perspectives.

\section{REFERENCES}

ASGHARI ZAMANI, A., ZADVALI KHAJE, S. \& ZADVALI, F. 2010. Survey of housing indicators in informal settlements areas. Case study: Seylab Neighborhood of Tabriz. Journal of Geographycal Notion, 4(8), pp. 44-61.

AZIMI-ĀMOLI, J. \& ERŠĀDI-VAHRĀM, S. 2017. Urban neighborhood management with an approach to participatory planning: A case study of urban neighborhoods in the Tehran region 1. Quarterly Journal of Geography (Regional Planning), 2(7), pp. 21-40.
BAÑULS, V.A. \& RUROFF, M. 2011.

Scenario construction via Delphi and cross-impact analysis. Technological Forecasting and Social Change, 78(9), pp. 1579-1602. https://doi. org/10.1016/j.techfore.2011.03.014.

BARTON, H., GRANT, M. \& GUISE, R. 2003. Shaping neighbourhoods: A guide for health, sustainability and vitality. Oxford: Taylor \& Francis.

BAZI, X., MIRKATULI, J. \& ZĀYEDLI, H.S. 2017. An evaluation of the role and effect of local councils on increasing citizen participation in urban neighborhood management: A case study of Gorgan. Geography and Development, 46(1), pp. 147-168.

BHATTACHERJEE, A. 2012. Social science research: Principles, methods, and practices. 2nd edition. Tampa, FL: University of South Florida.

BRADY, S.R. 2015. Utilizing and adapting the Delphi method for use in qualitative research. International Journal of Qualitative Methods, 14(5), pp. 1-6. https://doi. org/10.1177/1609406915621381.

BRAUN, V. \& CLARKE, V. 2006.

Using thematic analysis in psychology. Qualitative Research in Psychology, 3, pp. 77-101. https://doi. org/10.1191/1478088706qp063oa.

CLAYTON, M.J. 1997. Delphi: A technique to harness expert opinion for critical decision-making tasks in education. Educational Psychology, 17(4), pp. 373-386. DOI:10.1080/0144341970170401

FANNI, Z. \& KĀZEMI, L. 2016. Futures studies and scenario planning in neighborhood development planning based on system analysis by studying the Sangelaj neighborhood of Tehran. Strategic Studies of Public Policy, 21(6), pp. 15-29.

FANNI, Z. \& SĀREMI, F. 2008.

The challenges of the neighborhood management system in the sustainable development of Tehran metropolis. Soffeh, 47(17), pp. 91-108.

HENDRIKS, F. 2014. Understanding good urban governance: Essentials, shifts, and values. Urban Affairs Review, 50(4), pp. 553-576. https://doi. org/10.1177/1078087413511782. 
HOSSEIN POUR, M. 2017. Evaluation of housing physical indicators using sustainable development approach: Case study: Tabriz 2nd and 4th districts. MSc thesis, University of Tabriz, Iran.

JIBOYE, A.D. 2011. Sustainable urbanization: Issues and challenges for effective urban governance in Nigeria. Journal of Sustainable Development, 4(6), pp. 211-224. https://doi. org/10.5539/jsd.v4n6p211.

KEŠĀVARZ-TORK, A. \& BARĀTI, N. 2013. Futures studies in urban planning and management. Tehran: Tehran Urban Research \& Planning Center.

KIM, K.S. \& DICKEY, J. 2006. Role of urban governance in the process of bus system reform in Seoul. Habitat International, 30(4), pp. 10351046. https://doi.org/10.1016/j. habitatint.2005.09.010.

NA'IMI, K. \& PURMOHAMMADI, M.R. 2016. The identification of key factors affecting the future status of urban slums in Sanandij emphasizing the use of futures studies. Journal of Urban Studies, 20(1), pp. 53-64.

NEMATOLLAHI, S. 2015. The sociological analysis of unsustanability of urban development in informal settlements of metropolis: Case study of Tabriz. Journal of Sociology Studies, 8(26), pp. 37-51.

NURIYĀN, F. \& MOZAFFARIPUR, N. 2013. An evaluation of the neighborhood management function emphasizing social capital indicators: A case study of the seven neighborhoods of the Tehran region 21, area 1. Journal of Fine Arts, 4(18), pp. 47-56.

OKOLI, C. \& PAWLOWSKI, S.D. 2004. The Delphi method as a research tool: An example, design considerations and applications. Information \& Management, 42, pp. 15-29. https://doi. org/10.1016/j.im.2003.11.002.

PIŠGĀHI-FARD, Z., QALIBĀF, M.B., MORĀDI-NIA, S. \& MO'MENI, H. 2013. The pathology of the spatial distribution of political power in Tehran emphasizing urban governance. Geography, 38(11), pp. 93-112.

POWER, A. 2004. Neighbourhood management and the future of urban areas. LSE STICERD Research Paper No. CASE077.
RAJABI, Ā. 2011. Citizen participation methods in urban development processes. Quarterly Journal of Environmental Based Territorial Planning, 12(4), pp. 101-116.

RAZAVIYĀN, M.T., TAVAKKOLI-NIA, J., QURČI, M. \& ROSTAMI, Q. 2015. An evaluation of the neighborhood management function in the Ararat neighborhood of Tehran on the basis of the components of good urban governance. Geographical Urban Planning Research, 4(3), pp. 509-529.

REZĀ'I, M.R. \& MO'AZZEN, S. 2017. An evaluation of the relationship of neighborhoods management and urban governance in Tehran: A case study of the Tehran regions 1, 12 and 16 . Journal of Geography and Planning, 60(21), pp. 119-142.

REZAZADEH, R. 2011. Women empowerment and good urban governance in Iran. Asian Social Science, 7(3), pp. 260-268. https://doi. org/10.5539/ass.v7n3p260.

SHENG, Y.K. 2010. Good urban governance in Southeast Asia. Environment and Urbanization Asia, 1(2), pp. 131-147. https://doi. org/10.1177/097542531000100203.

TAQVĀ'I, A.A. \& TĀJDĀR, R. 2009. An introduction to good urban governance in an analytical approach. Urban Management, 23(1), pp. 45-58.

TAVAKKOLI, H. \& MO'MENI, M. 2016. The study of the realizability of the components of good urban governance emphasizing urban quality of life:

A case study of the Tehran regions 1 , 7 and 22. Urban Management Studies, 26(8), pp. 1-18.

VĀ'EZI, S.K., QOMIYĀN, M.M. \& VAQFI, S.H. 2017. Futures studies in the humanities with an approach to knowledge management:

Considerations, achievements and effects. Journal of Management of Governmental Organizations, 3(5), pp. 33-48.

VILLACORTA, P.J., MASEGOSA, A.D., CASTELLANOS, D. \& LAMATA, M.T. 2014. A new fuzzy linguistic approach to qualitative cross-impact analysis. Applied Soft Computing, 24, pp. 19-30. https://doi.org/10.1016/j. asoc.2014.06.025. 